\title{
Spectrophotometric Determination of Oxymetazoline Hydrochloride Via Oxidative Coupling Reaction with 4-Aminoantipyrine in the Presence of Potassium Periodate
}

\author{
Safaa A. Zakaria \\ Department of Chemistry \\ College of Science \\ University of Mosul
}

(Received 19/4 / 2011 ; Accepted 6/6/2011)

\begin{abstract}
A simple spectrophotometric method is developed for the determination of oxymetazoline hydrochloride $(\mathrm{OMCl})$ as pure and in its pharmaceutical preparations. The method is based on the oxidative coupling reaction of $\mathrm{OMCl}$ with 4-aminoantipyrine (4-A.A.P) in the presence of potassium periodate as oxidizing agent in an alkaline medium to produce a coloured water soluble product that is stable and has a maximum absorption at $480 \mathrm{~nm}$. Beer's law is obeyed in a concentration range $20-400 \mu \mathrm{g} \mathrm{OMCl} / 20 \mathrm{ml}$ with a molar absorptivity of $5.34 \times 10^{3} 1 . \mathrm{mol}^{-1} \cdot \mathrm{cm}^{-1}$, a relative error of -0.50 to $-1.47 \%$ and a relative standard deviation of \pm 0.36 to $\pm 1.58 \%$, depending on the concentration level. The optimum conditions for full colour development are described and the proposed method was applied successfully to the assay of $\mathrm{OMCl}$ in two pharmaceutical preparations.
\end{abstract}

Keywords : spectrophotometry ; oxidative coupling ; oxymetazoline ; 4-aminoantipyrine.

القدير الليف للأكسيمتازولين هيدوكلوربد بلستخدل فالى لافترل التأسسي مع 4 -

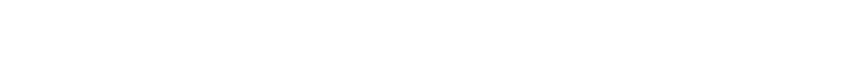

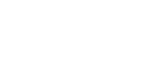

قم طويرطريقةطيفية لقندير الاوكسيمتازولين هيدروكلوري 2 بـ بشكله الح ـر وف مي مستح مضرالته

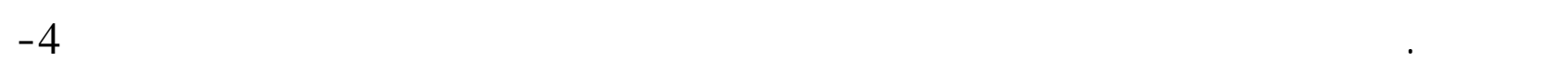
المينوالنتي بايرين بوجود العلمل المؤكسد بيريودات البوتلسيوم في وسط قاعدي لإعطاء نالتج ملون يكون ذائباً

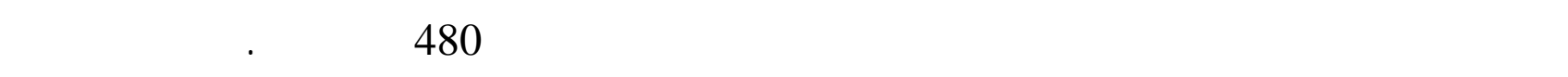

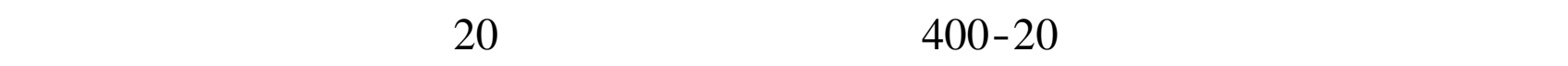

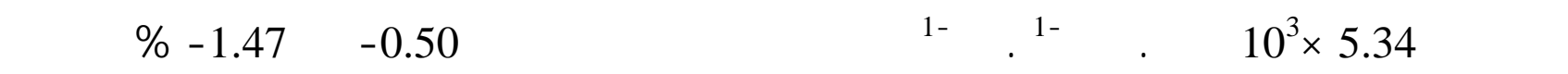

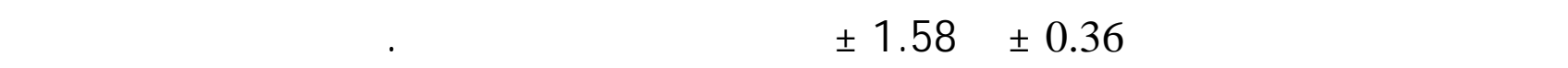


المثلى للفاعل وطقت الطريقة بنجاح في قدير الاوكسيمتازولين هيدروكلوريد ف ي مستح ضضرين داوئي ــن محضرن.

\section{INTRODUCTION}

Oxymetazoline hydrochloride is 3- [(4,5 - dihydro-1H-imidazol-2-yl)methyl]-6-(1,1dimethyl ethyl )-2,4-dimethyl-phenol hydrochloride( $\mathrm{OMCl}$ ), it is a white, crystalline powder, freely soluble in water and in alcohol, practically insoluble in ether (British Pharmacopia, 2000 ), its chemical formula and structure are as follows :<smiles>Cc1cc(C(C)(C)C)c(O)c(C)c1CC1=NCCN1</smiles>

$\mathrm{C}_{16} \mathrm{H}_{24} \mathrm{~N}_{2} \mathrm{O} . \mathrm{HCl}$

M.wt $=296.8 \mathrm{~g} / \mathrm{mol}$

$\mathrm{OMCl}$ is available as a topical decongestant in nasal sprays, it is also used to treat epistaxis and eye redness due to minor irritation, $\mathrm{OMCl}$ was developed by German patent Fruhstofer in 1961 (Wikipedia, 2008).

The large doses of $\mathrm{OMCl}$ may cause hypotension, presumably because of a central clonidine-like effect (Katzung, 2004).

Different methods have been used for the determination of OMCl such as a titrimetric method using ammonium metavandate as a reagent in acidic medium (Dwivedi et al., 2006), ion selective membrane electrode (Issa and Zayed, 2004), also, a flow injection method employing chemiluminescence detection (Garcia-Campana et al., 2004),the chromatographic methods are often the most analytical methods used such as high performance liquid chromatography (HPLC) (Stanisz and Nowinski, 2000 and Sundsakom et al., 2006), also, reversed-phase-HPLC (RP-HPLC) (Sane et al., 1990) and RP-HPLC used ion pair (Hoffmann et al., 1989) have been used in the determination of OMCl in pharmaceutical preparations.

Finally, a few spectrophotometric methods have been described for the determination of $\mathrm{OMCl}$, these methods included oxidation of $\mathrm{OMCl}$ with iron(III) and the librated iron(II) reacts with either (2,4,6-tris(2-pyridyl)-5-triazine to produce a maximum absorption at 595 $\mathrm{nm}$ (Snakar et al., 1988) or the ferrion complex which is measured at $510 \mathrm{~nm}$ is produced by oxidation-reduction between $\mathrm{OMCl}$ and ferric ion, (Al-Abd Alazeez, 2009),also, OMCl has been determined in pharmaceuticals by using 3,5-dinitrosalicylic acid ,(Al-Neaimy, 2006) and 2,6-dichloroquinone-chlorimide as a reagent (Snaker et al., 1987).

The literature review revealed that up today, nothing has been published concerning the use of 4-A.A.P as coupling reagent in the presence of potassium periodate in oxidative coupling reaction for determination of $\mathrm{OMCl}$ so that it is used in the present work to satisfactorily be applied for the determination of $\mathrm{OMCl}$ in dosage forms. 


\section{EXPERIMENTAL}

\section{Instruments :}

Spectrophotometric measurements are performed using Shimadzu UV-160 UV-Visible Recording Spectrophotometer and CEClL-CE 7200 UV-visible spectrophotometer using 1cm silica cells. The $\mathrm{pH}$ measurements are performed on $\mathrm{pH}$ meter type HANNA $211 \mathrm{pH}-\mathrm{Ion}$ meter.

\section{Reagents :}

All chemicals used in this investigation are analytical grade reagent.

Working OMCl solution, $(200 \mu \mathrm{g} / \mathrm{ml})$. A $0.02 \mathrm{~g}$ of $\mathrm{OMCl}$ is dissolved in distilled water and the volume is completed to the mark with distilled water in a 100-ml volumetric flask, the solution is kept in a brown bottle, where it is stable for at least one week.

4-Aminoantipyrine reagent, $\left(\mathbf{1 . 2 5 x 1 0}^{-3} \mathbf{M}\right)$. This solution is prepared by dissolving $0.025 \mathrm{~g}$ of pure 4-A.A.P reagent in distilled water and the volume made up to the mark in a 100-ml volumetric flask with the same solvent.

Sodium periodate solution, (0.015M). This solution is prepared by dissolving $0.3448 \mathrm{~g}$ of sodium periodate in distilled water and made up to $100 \mathrm{ml}$ in a volumetric flask with the same solvent.

Sodium hydroxide solution, (4N). This solution is prepared by appropriate dilution of the concentrated volumetric (Fluka) solution with distilled water to $250 \mathrm{ml}$ in a volumetric flask and then transferred to a plastic bottle.

Nazordin drops, $(200 \mu \mathrm{g} / \mathrm{ml})$. Provided from the State company for drug industries and medical appliances (SDI), Sammara-Iraq.

A three containers of drug (each contains $10 \mathrm{ml}$ of $0.05 \% \mathrm{OMCl}$ ) are mixed, then $20 \mathrm{ml}$ of the above solution was diluted with distilled water to $50 \mathrm{ml}$ in a volumetric flask to prepare a solution of $200 \mu \mathrm{g} / \mathrm{ml} \mathrm{OMCl}$.

_Oxymet drops, (200 $\mu \mathrm{g} / \mathrm{ml})$. Provided from pharaonia pharmaceuticals .

A three containers of drug (each contains $15 \mathrm{ml}$ of $0.025 \% \mathrm{OMCl}$ ) are mixed, then 40 $\mathrm{ml}$ of the above solution was diluted with distilled water to $50 \mathrm{ml}$ in a volumetric flask to prepare a solution of $200 \mu \mathrm{g} / \mathrm{ml} \mathrm{OMCl}$.

\section{RESULTS AND DISCUSSION}

The effect of various variables on the colour development of $200 \mu \mathrm{g}$ of $\mathrm{OMCl}, 1 \mathrm{ml}$ of 4-A.A.P and $2 \mathrm{ml}$ of $\mathrm{KIO}_{4}$ in alkaline medium( $(1 \mathrm{ml} 4 \mathrm{~N} \mathrm{NaOH})$ was tested to establish the optimum conditions.

\section{Choice of oxidizing agent with its concentration}

Different types of oxidizing agents were used to select the best one which will give the highest colour intensity (Table 1). 
Table 1 : Selection of oxidizing agent.

\begin{tabular}{|c|c|c|}
\hline 2ml Oxidizing agent 0.015M & Absorbance* & $\Delta \lambda^{* *}$ \\
\hline $\mathrm{KIO}_{4}$ & 0.129 & 186.5 \\
\hline $\mathrm{KIO}_{3}$ & 0.122 & 13 \\
\hline $\mathrm{K}_{2} \mathrm{CrO}_{4}$ & \multicolumn{2}{|c|}{ No colour contrast } \\
\hline $\mathrm{K}_{2} \mathrm{Cr}_{2} \mathrm{O}_{7}$ & \multicolumn{2}{|c|}{ No colour contrast } \\
\hline $\mathrm{N}$-chlorosuccinimide & 0.116 & 13 \\
\hline
\end{tabular}

*The flasks left on water bath for 30 minutes at $60^{\circ} \mathrm{C}$.

${ }^{* *} \Delta \lambda=\lambda^{\mathrm{S}}{ }_{\text {max }}-\lambda^{\mathrm{B}}{ }_{\text {max }}$; where $\mathrm{S}=$ the coloured product, $\mathrm{B}=$ blank.

The results illustrated in Table 1 indicated that $\mathrm{KIO}_{4}$ give the highest intensity of coloured product and a good colour contrast.

The effect of different volumes $(0.5-6 \mathrm{ml})$ of $\mathrm{KIO}_{4}$ solution $(0.015 \mathrm{M})$ on the colour intensity has been studied, it was observed that $4 \mathrm{ml}$ of $\mathrm{KIO}_{4}$ is the most suitable amount, since it gives the highest intensity of the formed product therefore it is chosen for further studies (Table 2).

Table 2 : The effect of $\mathrm{KIO}_{4}$ amount on absorbance.

\begin{tabular}{|c|c|c|c|c|c|c|c|}
\hline $\begin{array}{c}\text { Ml of KIO } \\
\text { (0.015M) }\end{array}$ & 0.5 & 1 & 2 & 3 & 4 & 5 & 6 \\
\hline Absorbance & 0.049 & 0.103 & 0.137 & 0.160 & 0.203 & 0.184 & 0.151 \\
\hline
\end{tabular}

\section{Effect of 4-A.A.P concentration}

Various volumes of 4-A.A.P $\left(1.25 \times 10^{-3} \mathrm{M}\right)$ were tested, the results indicated that using $2 \mathrm{ml}$ of 4-A.A.P solution gives maximum absorbance of the coloured product at $480 \mathrm{~nm}$ and the volume was considered as an optimum value(Table3).

Table 3 : Effect of reagent amount.

\begin{tabular}{|c|c|c|c|c|c|c|}
\hline Ml of 4-A.A.P (1.25x10 & -3 \\
\hline Mbsorbance & 0.5 & 1 & 2 & 3 & 4 & 5 \\
\hline Abse & 0.109 & 0.126 & 0.135 & 0.127 & 0.116 & 0.102 \\
\hline
\end{tabular}

\section{Choice of base and its amount}

The preliminary experiments have shown that $\mathrm{OMCl}$ can give high intensity of coloured dye with (4-A.A.P) in the presence of potassium periodate in alkaline medium,so that different types of bases are examined (Table 4).

Table 4 : Selection of base.

\begin{tabular}{|l|c|c|}
\hline 1ml of 4N Base & Absorbance & $\Delta \lambda^{*}$ \\
\hline $\mathrm{NaOH}$ & 0.202 & 202.5 \\
\hline $\mathrm{KOH}$ & 0.189 & 191 \\
\hline $\mathrm{Na}_{2} \mathrm{CO}_{3}$ & 0.117 & 42.5 \\
\hline $\mathrm{NaHCO}_{3}$ & 0.201 & 7.5 \\
\hline
\end{tabular}

$* \Delta \lambda=\lambda^{\mathrm{S}}{ }_{\max }-\lambda^{\mathrm{B}}{ }_{\text {max }}$; where $\mathrm{S}=$ the coloured product, $\mathrm{B}=$ blank. 
The results shown in Table 4 indicated that $\mathrm{NaOH}$ gives the highest colour intensity of product and a good colour contrast. Also, the effect of different volumes (0.5-4 ml) of $4 \mathrm{~N} \mathrm{NaOH}$ solution on the colour intensity has been studied,a $1 \mathrm{ml}$ of $4 \mathrm{~N} \mathrm{NaOH}$ with a final solution $\mathrm{pH}(13.15)$ gives the highest intensity of the formed product therefore it is used in subsequent experiments (Table 5).

Table 5 : Effect of base amount on absorbance.

\begin{tabular}{|c|c|c|c|c|c|}
\hline ml of 4N NaOH & 0.5 & 1 & 2 & 3 & 4 \\
\hline Absorbance & 0.183 & 0.200 & 0.173 & 0.161 & 0.152 \\
\hline pH & 12.92 & 13.15 & 13.37 & 13.50 & 13.67 \\
\hline
\end{tabular}

\section{Effect of surfactant}

The effects of different surfactants on the colour intensity were studied in four orders by using $3 \mathrm{ml}$ of various types of surfactant. The results showed that no effect of the surfactant had on the intensity (Table 6).

Table 6 : Effect of surfactant.

\begin{tabular}{|c|c|c|c|c|c|c|c|c|}
\hline \multirow{3}{*}{$\begin{array}{c}3 \mathrm{ml} \\
\text { Surfactant } \\
\text { Solution }\end{array}$} & \multicolumn{8}{|c|}{ Absorbance ${ }^{*} /$ order $^{* *}$ of addition } \\
\hline & \multicolumn{2}{|c|}{$\mathbf{I}$} & \multicolumn{2}{|c|}{ II } & \multicolumn{2}{|c|}{ III } & \multicolumn{2}{|c|}{ IV } \\
\hline & $\mathbf{A}$ & $\Delta \lambda^{* * *}$ & $\mathbf{A}$ & $\Delta \lambda$ & A & $\Delta \lambda$ & $\mathbf{A}$ & $\Delta \lambda$ \\
\hline $\begin{array}{c}\text { CPC } \\
1 \times 10^{-3} \mathrm{M}\end{array}$ & Turbid & ---- & Turbid & --- & Turbid & --- & Turbid & --- \\
\hline $\begin{array}{c}\text { SDS } \\
1 \times 10^{-3} \mathrm{M}\end{array}$ & 0.199 & 186.9 & 0.190 & 188.7 & 0.193 & 187 & 0.191 & 189 \\
\hline $\begin{array}{c}\text { Triton X-100 } \\
1 \%\end{array}$ & 0.086 & 189 & 0.089 & 187 & 0.081 & 190.2 & 0.075 & 191.7 \\
\hline
\end{tabular}

* Absorbance without surfactant (s) $=0.205$

** $\quad$ I. $\mathrm{OMCl}+\mathrm{S}+4$-A.A.P $+\mathrm{KIO}_{4}+\mathrm{NaOH}$

II. $\mathrm{OMCl}+$ 4-A.A.P $+\mathrm{S}+\mathrm{KIO}_{4}+\mathrm{NaOH}$

III. $\mathrm{OMCl}+$ 4-A.A.P $+\mathrm{KIO}_{4}+\mathrm{S}+\mathrm{NaOH}$

IV. $\mathrm{OMCl}+4-\mathrm{A} \cdot \mathrm{A} \cdot \mathrm{P}+\mathrm{KIO}_{4}+\mathrm{NaOH}+\mathrm{S}$

*** $\Delta \lambda=\lambda_{\max } \mathrm{S}-\lambda_{\max } \mathrm{B}$.

\section{Order of addition}

The effect of different orders of reagents addition were studied(Table 7).It was found that the order of reagents addition be followed as given under the general procedure give highest colour intensity, otherwise a loss in colour intensity takes place. 
Table 7 : Order of addition.

\begin{tabular}{|c|c|c|}
\hline Order of addition & Order number & Absorbance \\
\hline $\mathrm{OMCl}+4-\mathrm{A} . \mathrm{A} . \mathrm{P}+\mathrm{KIO}_{4}+\mathrm{OH}$ & $\mathrm{I}$ & 0.205 \\
\hline $\mathrm{OMCl}+\mathrm{KIO}_{4}+4-\mathrm{A} . \mathrm{A} . \mathrm{P}+\mathrm{OH}$ & $\mathrm{II}$ & 0.198 \\
\hline $\mathrm{KIO}_{4}+4-\mathrm{A} . \mathrm{A} . \mathrm{P}+\mathrm{OMCl}+\mathrm{OH}$ & $\mathrm{III}$ & 0.194 \\
\hline $\mathrm{OH}+4-\mathrm{A} . \mathrm{A} . \mathrm{P}+\mathrm{OMCl}+\mathrm{KIO}_{4}$ & $\mathrm{IV}$ & 0.203 \\
\hline $\mathrm{OH}+\mathrm{OMCl}+4-\mathrm{A} . \mathrm{A} . \mathrm{P}+\mathrm{KIO}_{4}$ & V & 0.205 \\
\hline $\mathrm{OH}+\mathrm{OMCl}_{4} \mathrm{KIO}_{4}+4-\mathrm{A} . \mathrm{A} . \mathrm{P}$ & VI & 0.162 \\
\hline $\mathrm{OH}+\mathrm{KIO}_{4}+4-\mathrm{A} . \mathrm{A} . \mathrm{P}+\mathrm{OMCl}$ & VII & 0.201 \\
\hline
\end{tabular}

\section{Effect of temperature}

The effect different of temperatures on the colour intensity of resulting complex were investigated. The results indicated that the absorbance of complex increased with increasing temperature, the high value of absorbance was obtained at $70^{\circ} \mathrm{C}$ then a decrease in colour intensity was observed as the temperature increase above $70^{\circ} \mathrm{C}$ (Table 8).

Table 8 : Effect of temperature.

\begin{tabular}{|c|c|c|c|c|c|c|}
\hline Temperature $\left(\mathbf{(}^{\mathbf{C}} \mathbf{C}\right)$ & 40 & 50 & 60 & 70 & 80 & 90 \\
\hline Absorbance & 0.098 & 0.171 & 0.205 & 0.238 & 0.229 & 0.219 \\
\hline
\end{tabular}

The effect of the time needed to complete the oxidative coupling reaction had been studied at $70^{\circ} \mathrm{C}$ and the results showed that a maximum intensity occurred at 25 minutes before dilution of the flask with distilled water (Table 9).

Table 9 : The effect of time on absorbance at $70 \mathrm{C}^{0}$.

\begin{tabular}{|c|c|c|c|c|c|c|c|c|c|}
\hline Time (min.) & 0 & 5 & 10 & 15 & 20 & 25 & 30 & 35 & 40 \\
\hline Absorbance & 0.042 & 0.098 & 0.120 & 0.211 & 0.240 & 0.242 & 0.232 & 0.226 & 0.223 \\
\hline
\end{tabular}

\section{Development time and stability period}

The stability time of the formed coloured complex is investigated under the optimum conditions for the determination of $\mathrm{OMCl}$, the experimental results (Table 10) showed that the coloured complex formed is complete after 15 minutes from removing of the flasks from water bath and the absorbance remained constant at least for one hour.

Table 10 : Effect of colour stability time.

\begin{tabular}{|c|c|c|c|c|c|c|c|c|}
\hline \multirow{2}{*}{$\begin{array}{c}\text { fg of OMCl } \\
\text { present }\end{array}$} & \multicolumn{7}{|c|}{ Absorbance/min. standing time } \\
\cline { 2 - 9 } & $\mathbf{5}$ & $\mathbf{1 0}$ & $\mathbf{1 5}$ & $\mathbf{2 0}$ & $\mathbf{3 0}$ & $\mathbf{4 0}$ & $\mathbf{5 0}$ & $\mathbf{6 0}$ \\
\hline $\mathbf{1 0 0}$ & 0.145 & 0.145 & 0.145 & 0.145 & 0.145 & 0.145 & 0.145 & 0.145 \\
\hline $\mathbf{2 0 0}$ & 0.241 & 0.241 & 0.241 & 0.241 & 0.241 & 0.240 & 0.239 & 0.239 \\
\hline $\mathbf{3 0 0}$ & 0.323 & 0.323 & 0.323 & 0.323 & 0.323 & 0.323 & 0.322 & 0.320 \\
\hline
\end{tabular}




\section{Final absorption spectrum}

When $\mathrm{OMCl}$ was treated according to recommended procedure, the absorption spectrum showed a maximum absorption at $480 \mathrm{~nm}$ versus the reagent blank (Fig. 1).

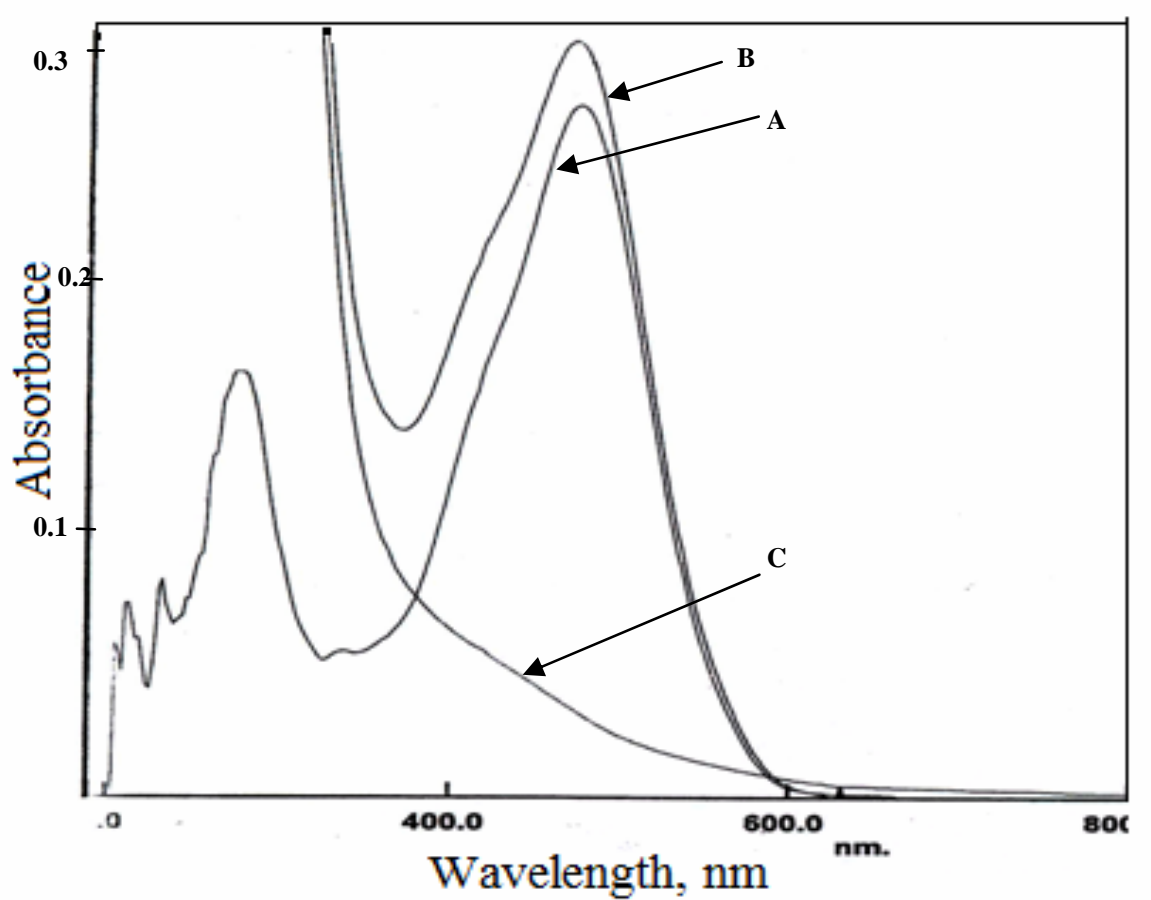

Fig1 : Absorption spectrum of (A) the coloured product (from 200 $\mu$ g OMCl) against blank, (B) complex against distilled water and (C) blank against distilled water.

\section{Recommended procedure and calibration curve}

To a series of $20-\mathrm{ml}$ volumetric flasks, $0.1-3 \mathrm{ml}$ of $200 \mu \mathrm{g} \cdot \mathrm{ml}^{-1} \mathrm{OMCl}$ solution are transferred then $2 \mathrm{ml}$ of 4 -A.A.P reagent $\left(1.25 \times 10^{-3} \mathrm{M}\right)$ and $4 \mathrm{ml}$ of potassium periodate $(0.015 \mathrm{M})$ are added. After that a $1 \mathrm{ml}$ of $4 \mathrm{~N}$ sodium hydroxide solution was added. The solutions were left for 25 minutes in water bath adjusted at $70^{\circ} \mathrm{C}$, then the volumes were completed to the mark with distilled water and left to stand for 15 minutes at room temperature, after that the absorbances are measured at $480 \mathrm{~nm}$ against the reagent blank.

The calibration graph is linear over the concentration range of $20-400 \mu \mathrm{g} / 20 \mathrm{ml}$ (Fig.2). The apparent molar absorptivity referred to $\mathrm{OMCl}$, has been found to be $5.34 \times 10^{3}$ $1 . \mathrm{mol}^{-1} \cdot \mathrm{cm}^{-1}$. 


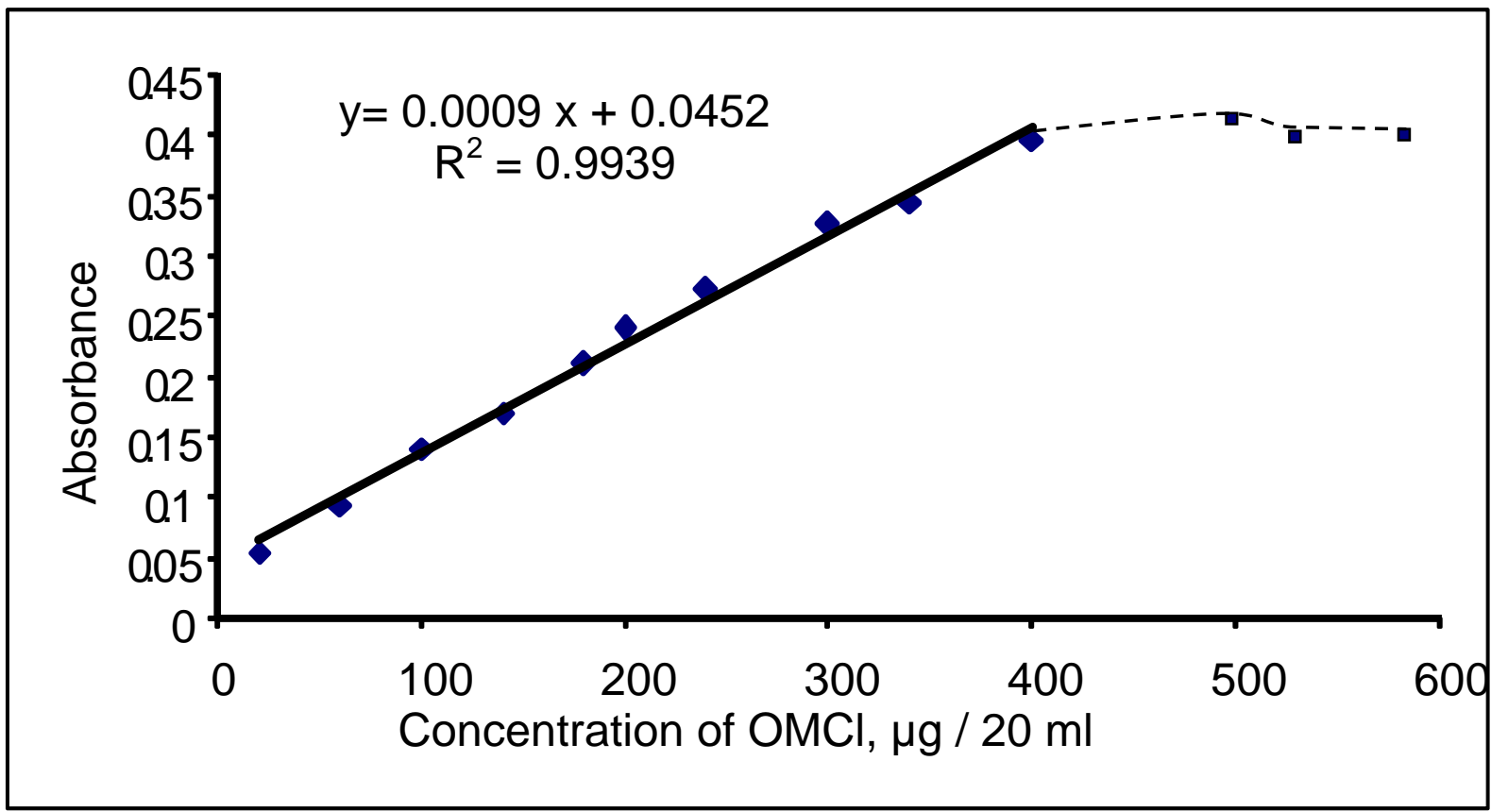

Fig. 2: The calibration curve of OMCl determination.

\section{Accuracy and precision}

To determine the accuracy and precision of the method, $\mathrm{OMCl}$ was determined at three different concentrations. The results shown in table (11), indicate that a satisfactory accuracy and precision could be obtained with the proposed method.

Table 11 : Accuracy and precision of the proposed method.

\begin{tabular}{|c|c|c|}
\hline OMCl $(\boldsymbol{\mu g} / \mathbf{2 0 m l})$ & Relative error, $\%$ & Relative standard deviation \% \\
\hline $\mathbf{1 0 0}$ & -1.476 & \pm 1.580 \\
\hline $\mathbf{2 0 0}$ & -0.826 & \pm 0.869 \\
\hline $\mathbf{3 0 0}$ & -0.507 & \pm 0.365 \\
\hline
\end{tabular}

* Average of five determinations.

\section{The nature of the reaction product}

Job's method of the continuous variations (Fig.3) indicates that the coloured product has a compostion of 1:2 $\mathrm{OMCl}$ to 4 -A.A.P reagent at $480 \mathrm{~nm}$. 


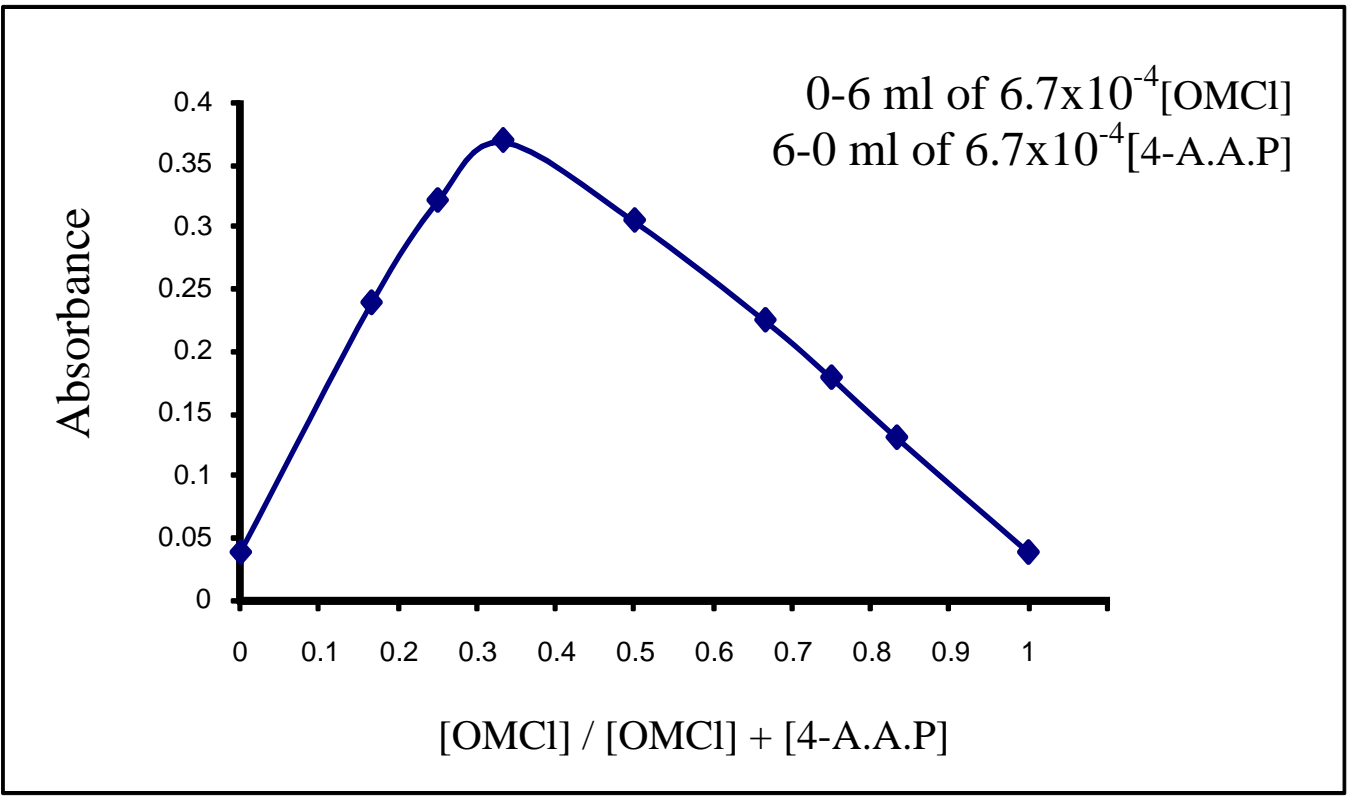

Fig. 3 : Job's plot for OMCl -4-A.A.P coloured product.

Therefore, the probable reaction path might be written as follows:

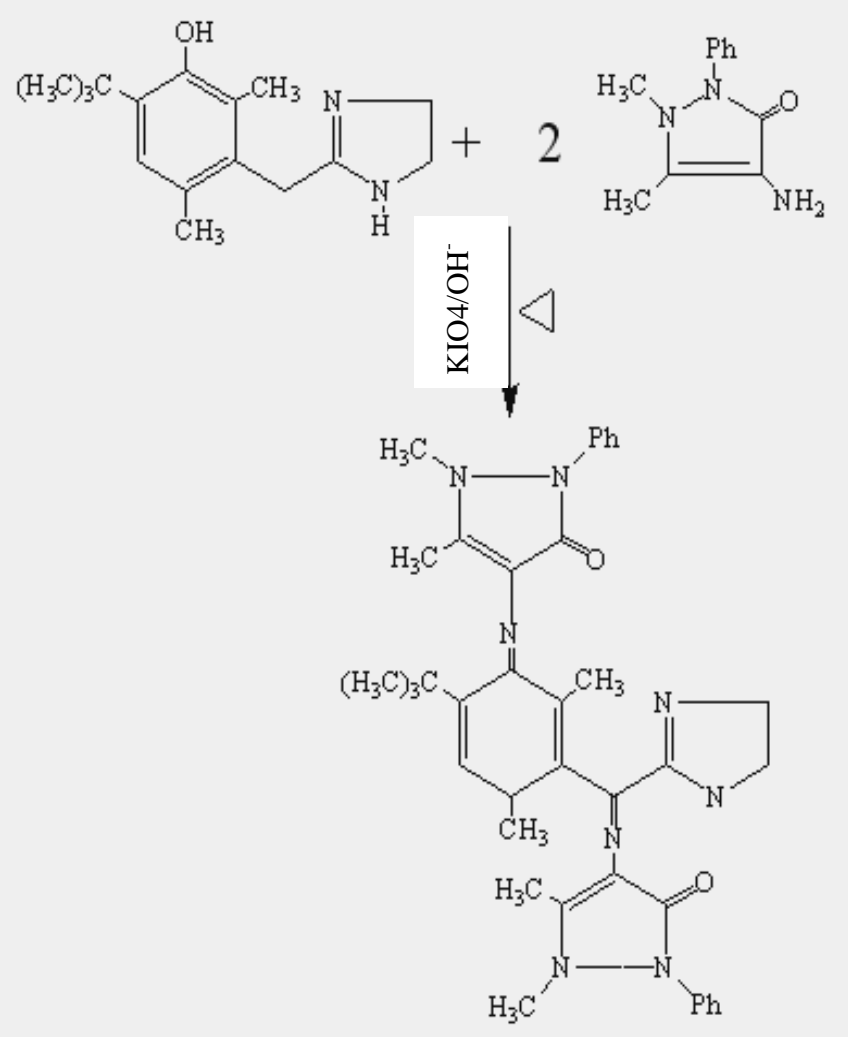




\section{Evaluation of the proposed method :}

Because the standard method for the determination of $\mathrm{OMCl}$ included potentiometric titration, according to difficulties of availability of using it, so that standard addition method was used in order to prove that the proposed method can be applied to determination of $\mathrm{OMCl}$ in pharmaceutical preparations. (Table 12 and Fig. 4).

Table 12 : The results of standard addition method.

\begin{tabular}{|c|c|c|c|}
\hline Drug & $\begin{array}{c}\mu \mathbf{g} \text { OMCl } \\
\text { present/20 ml }\end{array}$ & $\begin{array}{c}\mu \mathbf{g} \text { OMCl } \\
\text { measured/20 ml }\end{array}$ & Recovery ${ }^{*}, \mathbf{\%}$ \\
\hline Nazordin 0.05\% & 80 & 79 & 98.75 \\
\cline { 2 - 4 } S.D.I-Iraq & 120 & 118 & 98.33 \\
\hline $\begin{array}{c}\text { Oxymet 0.025\% } \\
\text { Pharaonia (Egypt) }\end{array}$ & 80 & 82 & 102.50 \\
\cline { 2 - 4 } & 120 & 124 & 103.33 \\
\hline
\end{tabular}

* Average of three determinations.

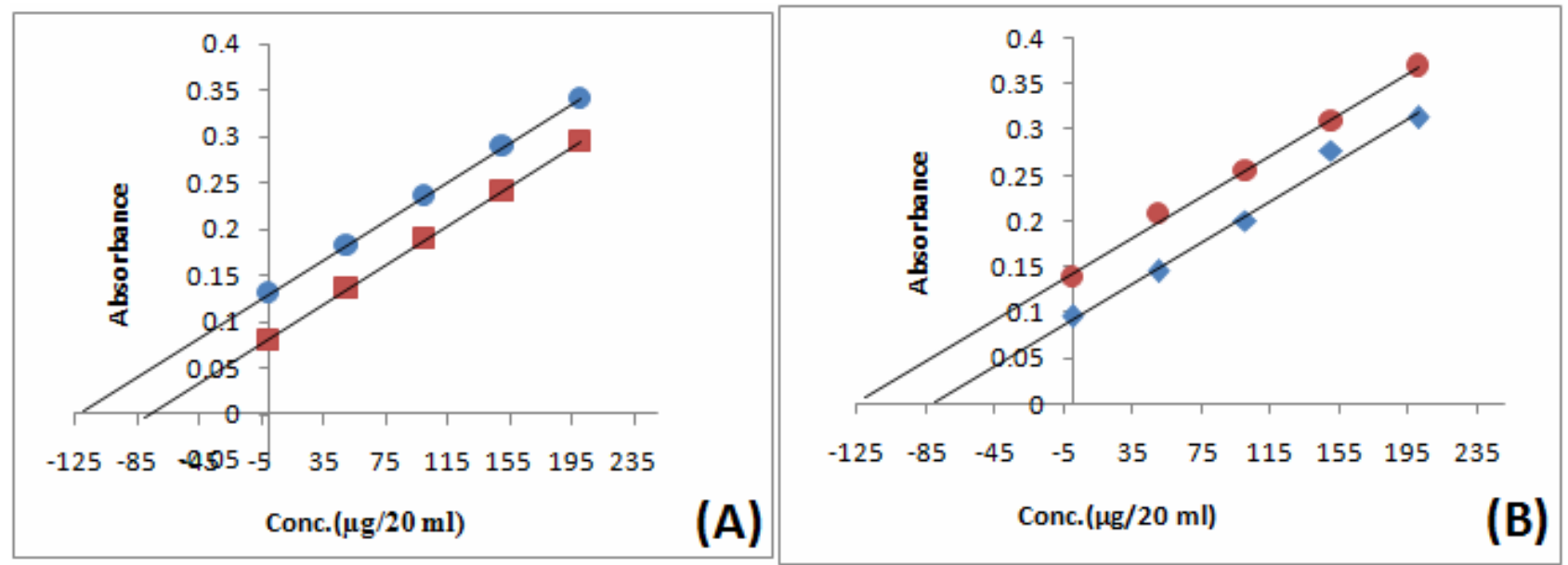

Fig 4: Calibration standard addition graph for the determination of $\mathrm{OMCl}$ in Nazordin (A) and Oxymet (B)

The results in Table 12 and Fig.4 indicated that the proposed method can be used to determine $\mathrm{OMCl}$ in pharmaceutical preparation with satisfactory results.

Table 13 shows the comparison between some of analytical variables obtained from the present method with that of a recent spectrophotometric method. 
Table13: Comparision of the method.

\begin{tabular}{|c|c|c|}
\hline Conditions & Present Method & Literature Method* \\
\hline$\lambda_{\max }(\mathrm{nm})$ & 480 & 510 \\
\hline Temperature $\left({ }^{\circ} \mathrm{C}\right)$ & 70 & 70 \\
\hline Beer's law & $1-20$ & $0.1-7$ \\
\hline $\begin{array}{c}\text { Molar absorptivity } \\
1 . \mathrm{mol}^{-1} \cdot \mathrm{cm}^{-1}\end{array}$ & $5.34 \times 10^{3}$ & $5.74 \times 10^{4}$ \\
\hline Stability of the colour & At least one hour & $\ldots \ldots$ \\
\hline RSD(\%) & $0.36-1.58$ & $0.72-1.6$ \\
\hline Type of reaction & Oxidative coupling & Oxidation-reduction \\
\hline Applications & $\begin{array}{l}\text { Nazordin } 0.05 \% \\
\text { Oxymet } 0.025 \%\end{array}$ & $\begin{array}{l}\text { Nazoden } 0.025 \% \\
\text { Oxymet } 0.05 \%\end{array}$ \\
\hline
\end{tabular}

*Al-Abd Alazeez, B.A.R. (2009), M.Sc. Thesis, Mosul University, pp. 93-108.

The results indicate that the proposed method is sensitive and stable compared with the literature method .

\section{CONCLUSION}

A simple and sensitive spectrophotometric method for the determination of $\mathrm{OMCl}$ in aqueous solution based on the reaction of $\mathrm{OMCl}$ with 4-A.A.P in the presence of $\mathrm{KIO}_{4}$ is developed. The proposed method has been successfully applied to assay $\mathrm{OMCl}$ in pharmaceutical preparations.

\section{REFERENCES}

Al-Abd Alazeez, B.A.R. (2009). Development of indirect spectrophotometric methods for determination of some nitroaromatic _ and phenolic drugs. M.Sc. Thesis, Mosul University, pp. 93-108.

Al-Neaimy, U.I. (2006). The use of 3,5-dinitrosalicylic acid in spectrophotometric determinations of organic and drug compounds. Ph. D., Thesis, Mosul University, pp. 82-104.

"British Pharmacopoeia on CD-ROM", (2000). 3rd. edn., System Simulation Ltd, Stationary Office, London.

Dwivedi, P.K.; Dubey, B.K.; Shukla, I.C. (2006). Application of ammonium meta vanadate for the determination of some ophthalmic compounds, Oriental J. Chem., 22(1). 
Garcia-Compana, A.M.; Sendra, J. M. B.; Vargas, M.P.B.; Baeyens W.R.G.; Zhang X. (2004). Flow injection analysis of oxymetazoline hydrochloride with inhibited chemiluminesscent detection, Anal. Chim. Acta, 516, 245-249.

http://www.wikipedia.org/wiki/ oxymetazoline, 2008.

Hoffmann, T.J.; Thompson, R.D.; Seifert, J.R. (1989). Determination of nasal decongestant, oxymetazoline hydrochloride, in pharmaceutical formulation by HPLC. Drug development and industrial pharmacy, 15, 743-757.

Issa, Y.M.; Zayed, S.I.M.; (2004). Construction and analytical applications of plastic membrane electrode for oxymetazoline hydrochloride. Anal. Sci., 20, 297.

Katzung, B.G. (2004). "Basic and Clinical Pharmacology", 9th edn., McGraw-Hill Companies, USA, $134 \mathrm{p}$.

Sane, R.; Joshi, L.; Latage, K.; Kothurkar, R.; Bhate, V. (1990). High performance liquid chromatographic determination of oxymetazoline hydrochroride from nasal drop, India J. Pharm. Sci., 52, 38-39.

Snakar, D.G.; Sastry, C.S.P.; Ready, M.N.; Akuna, M. (1988). Spectrophotometric determination of some adernergic agents using iron(III) and 2,4,6-tris(2-pyridyl)-5triazine, Ind. J. Pharm. Sci., 50, 178-180.

Snakar, D.G.; Sastry, C.S.P.; Ready, M.N.; Prasad, S.I.R. (1987). Spectrophotometric determination of some adernergic agents using 2,6-dichloroquinone-chlorimide, Ind. J. Pharm. Sci., 49-69.

Starsz, B.; Nowinski, W. (2001). Determination of oxymetazoline hydrochloride and decomposition by high performance liquid chromatography, Acta Poloni. Pharm., 57, 344-401.

Sudsakorn, S.; Kaplan, L.; Williams, D.A. (2006). Simultaneous determination of triamcinolone acetonid and oxymetazoline hydrochloride in nasal spray formulation by HPLC, J. Pharm. Biomed. Anal., 40, 1273-1280. 